\title{
Thin ice impacts on surface salt flux and ice strength: Inferences from advanced very high resolution radiometer
}

\author{
Y. Yu, D. A. Rothrock, and J. Zhang \\ Polar Science Center, Applied Physics Laboratory, College of Ocean and Fishery Sciences, University of Washington \\ Seattle, Washington
}

\begin{abstract}
Temperatures and albedos derived from satellite imagery are combined with a thermodynamic ice model to estimate thin ice thickness distributions over the Beaufort and the northern Greenland seas. The study shows that thin ice (thinner than $1 \mathrm{~m}$ ) occupied over half the area in the seasonal ice zones in November and December of 1990 but dropped significantly in April 1991; the Beaufort Shelf showed the largest seasonal change. The aggregate properties of surface salt flux and compressive ice strength, both strongly dependent on the thin end of the ice thickness distribution, were estimated with data from advanced very high resolution radiometer to reveal the spatial and temporal variations over a large scale. The salt flux from growing thin ice was 1-2 orders of magnitude larger on the Beaufort and Greenland Shelves than in the deep basins. On the shelves, flux from thin ice accounted for over $90 \%$ of the total surface salt budget. These satellite-derived estimates provided detailed spatial information on salt flux, which can be of great use in studies of surface patterns of salinity forcing and shelf-basin interaction. Also revealed by the satellite data was the wide range in values of compressive strength, which affects how freely the ice cover can deform. Strengths were low in early winter and in seasonal ice zones and nearly doubled in spring. Both thin ice fraction and compressive ice strength estimated from satellite imagery were in good agreement with those simulated by a coupled ice-ocean model.
\end{abstract}

\section{Introduction}

Monitoring the seasonal and interannual behavior of sea ice properties with NOAA satellites is both an opportunity and a challenge. The opportunity arises from twice daily overpasses, which provide excellent coverage of the polar ocean. The challenge lies with the surface being sampled. Sea ice appears radiometrically similar in the imagery of advanced very high resolution radiometer (AVHRR), making it difficult to monitor, for example, the mass of the sea ice cover. Compromises in which useful ice properties match what satellites can distinguish must be made.

One useful property is the surface area and thickness of thin ice, defined here as ice with thickness $<1 \mathrm{~m}$. In winter, thin ice has a warmer surface and appears darker than the surrounding thicker ice; these thermal contrasts form the basis for the approach followed in this paper. An example of a clear-sky AVHRR image over the southern Canada Basin shows the leads as linear, dark red and orange features that are $10^{\circ}-20^{\circ} \mathrm{C}$ warmer than the thick floes (Plate 1). Since thin ice in leads responds rapidly to changes in wind and temperature and is generally covered with no or little snow, the thickness of thin ice, not just its presence, can be inferred directly from the radiative surface temperature detected by the satellite.

Fortuitously, several aggregate properties are sensitive to thin ice and can be largely or completely determined by thin ice when it occupies a substantial portion of the total surface area. Two such properties are the flux to the ocean surface of salt rejected from growing thin ice and the mechanical

Copyright 2001 by the American Geophysical Union

Paper number 2000JC000311.

0148-0227/01/2000JC000311\$09.00 strength of the ice cover. Figure 1 shows an annual cycle of salt flux from both thin and thick ice. While the thick ice continues melting (negative salt flux) in September, thin ice grows vigorously as the air cools. The growing thin ice dominates the total salt budget until January, when thicker ice reaches the peak of its growth cycle. In the annual mean, brine rejection from thin ice is about 8 times larger than that from thicker ice, profoundly affecting the density structure of underlying water.

Thin ice also controls the compressive strength $p^{*}$ and thus the mechanical behavior of sea ice. High percentages of thin ice reduce the stresses transmitted among ice floes and make pressure ridges more likely to form. The compressive ice strength can be related explicitly to the thin end of the ice thickness distribution [e.g., Rothrock, 1975]:

$$
p^{*}=\left(k C_{p}+\frac{k}{(k-1)} C_{f}\right) \int_{0}^{\infty} h^{2} a(h) d h,
$$

where $k$ is the ratio of thickness after and before ridging, $C_{p}$ and $C_{f}$ are strength parameters, $h$ is ice thickness (before ridging), and $a(h)$ is the participation function that describes the distribution of thin ice lost during ridging. Figure 2 shows how $a(h)$ varies given a particular thickness distribution $G(h)$. Here the common assumption is made that the thinnest $15 \%$ of the ice cover joins the ridging, whereas the thicker ice provides the indestructible matrix that forces the thinner ice to ridge. So, when at least $15 \%$ of the ice is thinner than $1 \mathrm{~m}$, the strength is determined entirely by what the satellite can observe.

In this paper we demonstrate the application of satellite thermal imagery to the estimation of these two quantities: salt flux and ice strength. We first review the notion of the ice thickness distribution, which describes the mixture of ice of 

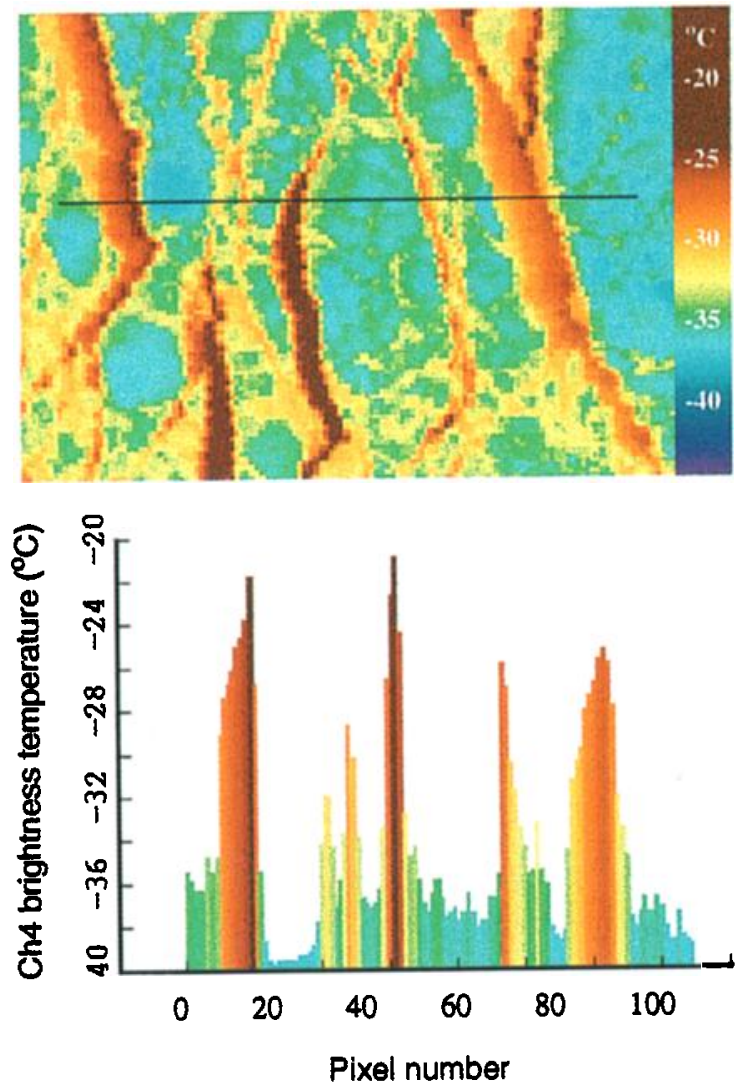

Plate 1. (top) An example of AVHRR imagery over an area of the southern Canada Basin on December 7, 1990, and (bottom) a temperature profile along a $128 \mathrm{~km}$ transect indicated by the black line. A pixel is about $1 \mathrm{~km}$.

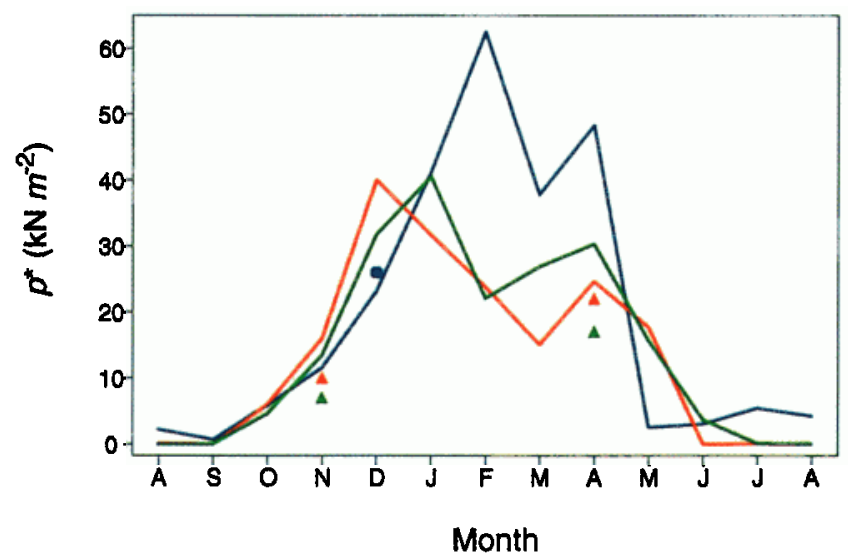

Plate 2. Modeled annual variation in $p^{*}$ for three selected cells: cell 13 in the Beaufort Sea (blue line) and cells 9 and 14 in the Greenland Sea (red and green lines, respectively), from August 1990 to August 1991. The colored symbols mark the monthly values estimated from AVHRR and match the line with the same color. 


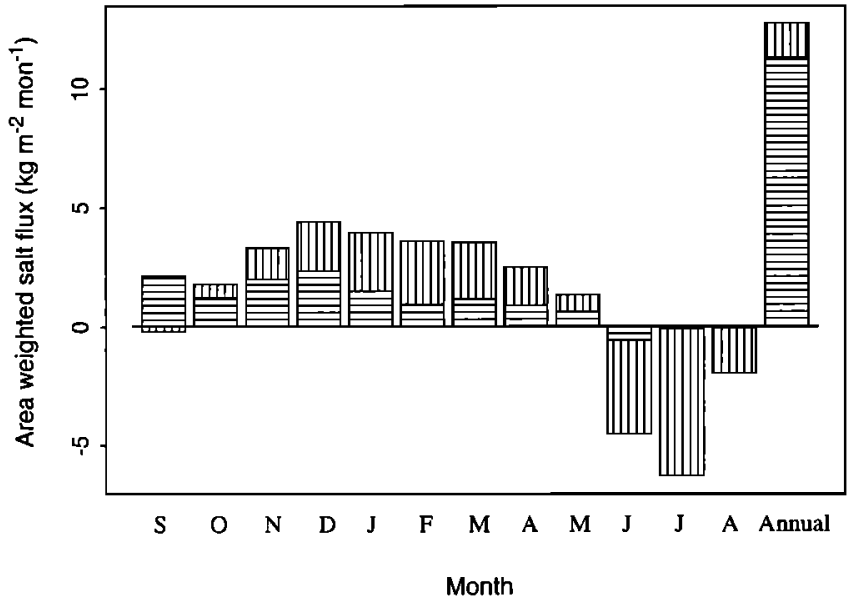

Figure 1. Seasonal variations of salt flux from ice thinner than $0.8 \mathrm{~m}$ (horizontal hatches) and from thicker ice (vertical hatches) [after Maykut, 1985]. A positive flux denotes input of salt to the ocean mixed layer due to ice freezing, and a negative flux denotes input of fresh water due to ice melting.

various thicknesses within an area; here our sample areas are taken to be roughly $200 \mathrm{~km}$ square. In a study by $Y u$ and Rothrock [1996] (hereinafter referred to as YR96), AVHRR measurements of surface temperature and albedo were combined with a one-dimensional thermodynamic ice model to estimate quantitatively the thickness of thin ice and its distribution. Comparisons with measurements from upward looking sonar (ULS) moorings showed that AVHRR-derived estimates were sufficiently accurate to resolve typical regional and seasonal changes in thin ice thickness distribution. Figure 3 is an example of AVHRR-derived thickness. Most of the thin ice is about $0.3 \mathrm{~m}$ thick and coincides with the lead system. In this example, thin ice accounts for about $30 \%$ of the total surface area along the transect.

We also describe how salt flux and ice strength depend on the thickness distribution and are particularly weighted to the thin ice portion of this distribution. We illustrate the AVHRR scenes used to estimate many thin ice thickness distributions and show how these distributions vary from area to area, how they vary between the Beaufort and the Greenland Seas, and

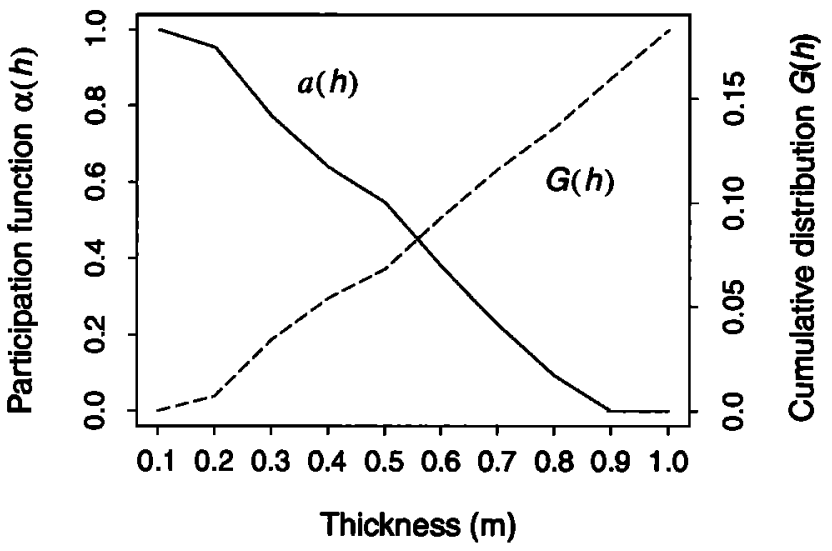

Figure 2. Relationship between ice thickness and participation function (solid line) for a thickness distribution (dashed line) observed in the Beaufort Sea in December 1990.
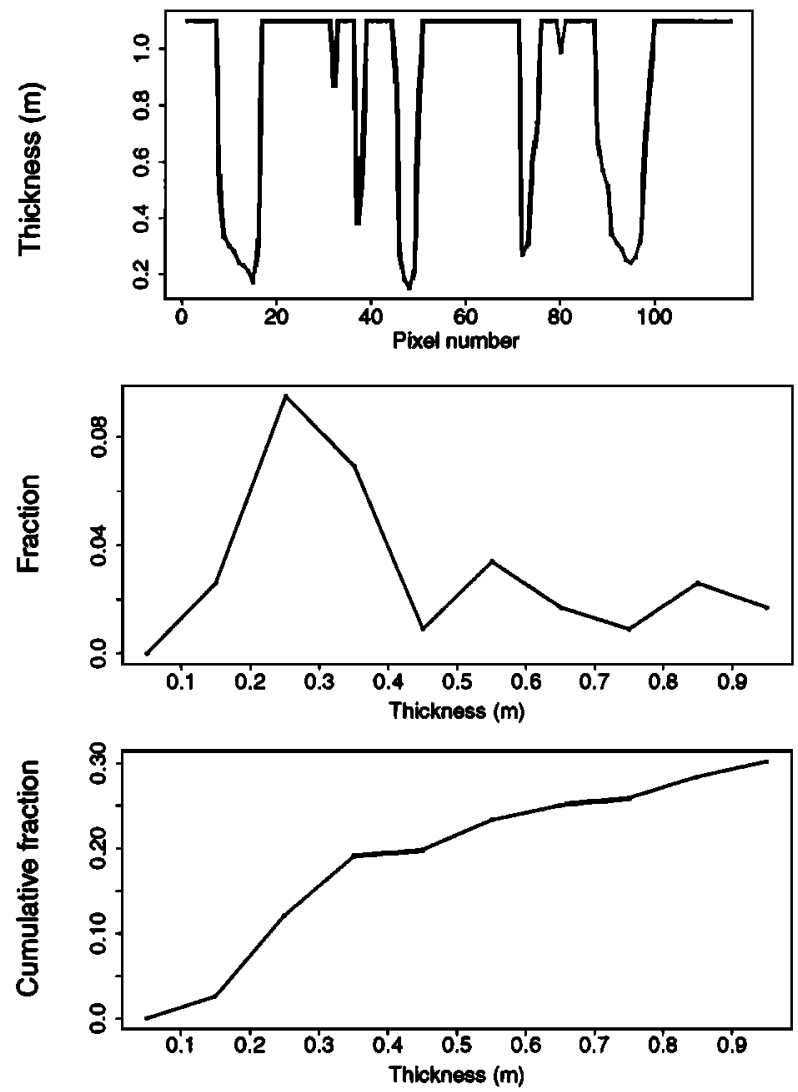

Figure 3. (a) Variation of AVHRR-derived thin ice thickness along the transect shown in Plate 1. Pixels with ice thicker than $1 \mathrm{~m}$ are artificially set at $1.1 \mathrm{~m}$. (b) Thickness distribution and (c) its cumulative distribution.

how they change from early to late winter. Then we show that in many of these cases, considerable information about salt flux and strength can be deduced from the imagery. Finally, we compare AVHRR-derived ice strength with model simulations and show that it is important to retain adequate resolution of the thin end of the thickness distribution.

\section{Data Description}

\subsection{AVHRR Data}

The satellite data used in the study are from NOAA satellites 10 and 11. The AVHRR on NOAA 11 has five channels, ranging from visible to the thermal infrared: $0.58-0.65,0.72-0.10,3.55-3.93,10.3-11.3$, and $11.5-12.5 \mu \mathrm{m}$. On NOAA 10 the fifth channel repeats the window of channel 4. The sensor provides about $2900 \mathrm{~km}$ wide coverage, with a relative fine resolution of $1.1 \mathrm{~km}$ at nadir and $2.5 \times 6.7 \mathrm{~km}$ at the edge of the swath. The AVHRR data were first calibrated and then warped onto a $1.1 \mathrm{~km}$ grid with a polar stereographic projection. Data from channels 1 and 2 were converted to reflectance, and data from channels 3,4 , and 5 were converted to temperature. Pixels at satellite scan angles larger than $45^{\circ}$ were rejected to retain adequate ground resolution and to avoid the increased atmospheric attenuation. While various algorithms have been developed to screen clouds, no reliable algorithms have been developed so far for the Arctic dark season. Since half of the images used in the study were 


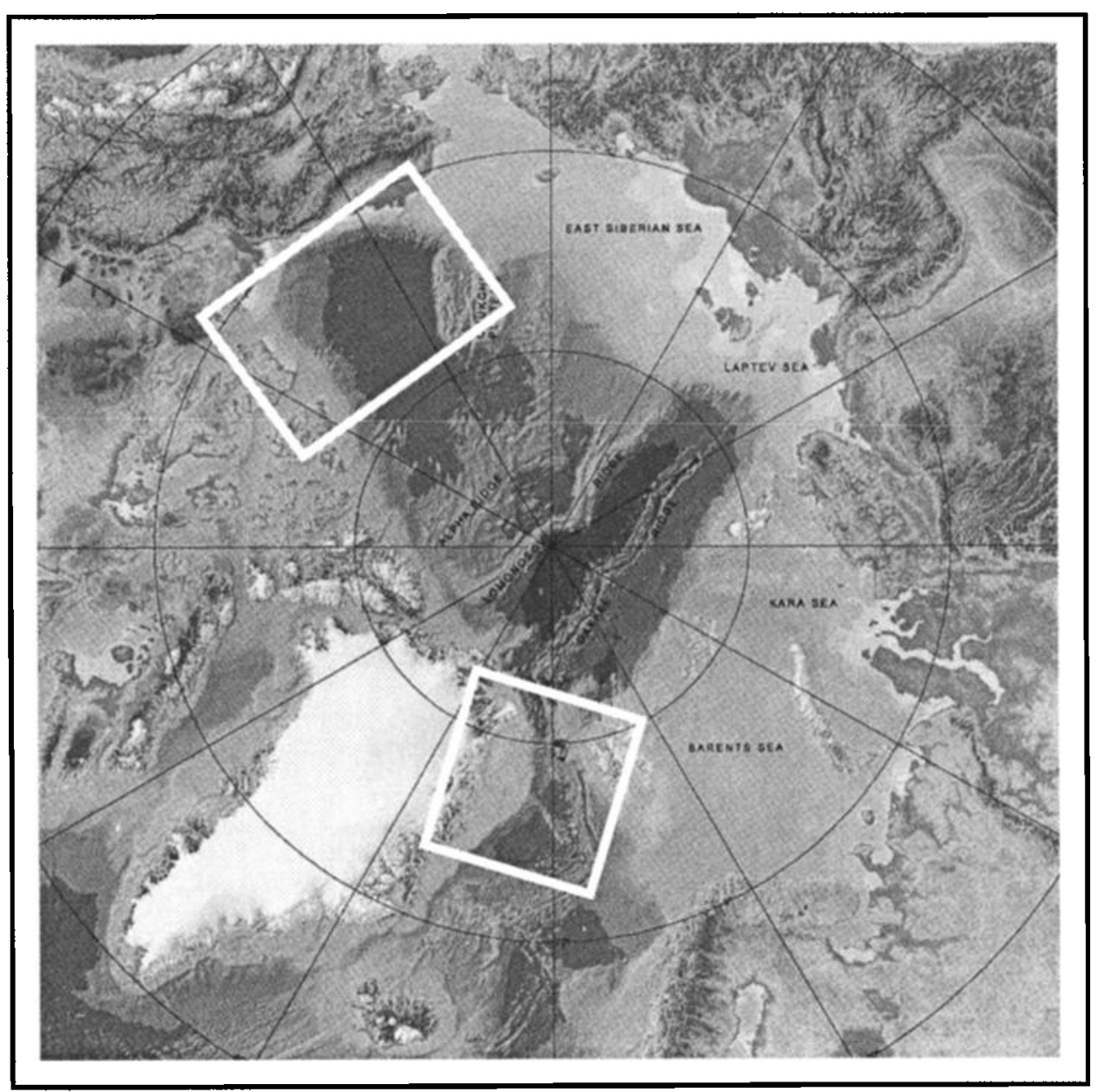

Figure 4. Bathymetric and topographic shaded relief north of $60^{\circ} \mathrm{N}$ (http://www.ngdc.noaa.gov/mgg/image/ IBCAO_betamap.jpg). The study regions are indicated approximately by the two white boxes.

obtained when there was no sunlight, we used a subjective manual procedure that uses combinations of all possible channels and visual identification. Low-level clouds and subpixel clouds likely remain a source of uncertainty.

The selected images come from two regions and two time periods: the Beaufort Sea in December 1990 and April 1991 and the northern Greenland Sea in November 1990 and April 1991. The months in 1990 represent the early part of the ice growing season, and April represents the later part of the ice growing season.

\subsection{Regions of Interest}

The white rectangular boxes in Figure 4 show our two study regions; each exhibits unique ice conditions. The Beaufort Sea, indicated by the upper box in Figure 4 , is bounded to the south by the shallow continental shelf, where first-year ice and leads predominate. Along the coast, landfast ice is common; its growth in winter depends largely on the surface air temperature. Away from the coast the ice cover becomes more mobile under the influence of both winds and currents. Ice motion creates large stresses and mechanical deformations, causing continual ridging and openings and thus creating new areas for ice to grow.

In the northern Greenland Sea, indicated by the lower box in Figure 4, the thickness depends not only on the aging history of the ice but also on the origin of the ice in the Arctic Basin. Ice moving toward Fram Strait along the northeast Greenland coast is composed of many thick, deformed multiyear floes with locally heavy ridging, whereas the ice north of Spitsbergen and over the Yermak Plateau consists of thin, younger sea ice mostly formed on the shelves of the eastern Arctic. Ice cover on the East Greenland Shelf, especially along the ice margin, is highly populated with open water and thin ice between fractured ice floes, a characteristic very different from that seen in the Beaufort Sea.

\section{Spatial and Temporal Variations of Thin Ice Cover}

\subsection{Deriving Thin Ice Thickness With Surface Heat Balance}

To determine quantitatively thin ice distribution from AVHRR imagery, thickness was estimated first at each satellite pixel and then all pixels in each scene were summed to compute the thickness distribution. We used a onedimensional thermodynamic ice model containing all components of surface turbulent heat and radiative fluxes. This slab model solves for the thickness $h$ of thin ice with a uniform snow cover of thickness $h_{s}$ on ice thicker than $5 \mathrm{~cm}$. The energy balance at the top surface (whether ice or snow) in the cold season is 


$$
\left(1-a_{s}\right) F_{r}-I_{0}-F_{l}^{\mathrm{up}}+F_{l}^{\mathrm{din}}+F_{s}+F_{e}+F_{C}=0 .
$$

The first term, together with AVHRR-derived surface albedo $\alpha_{s}$, describes the net solar radiation. The incoming solar radiation $F_{r}$ was estimated from the following empirical relation for clear-sky conditions [Shine and HendersonSellers, 1985]:

$$
F_{r}=1368.0 \mu\left[1.2 \mu+(1.0+\mu) e_{a} 10^{-3}+0.046\right]^{-1} .
$$

The second term in (3) is the solar radiation that passes through the interior of the ice:

$$
I_{0}=i_{0}\left(1-\alpha_{s}\right) F_{r} .
$$

Both the first and second terms in (3) are zero during dark seasons.

The upward longwave radiation $F_{l}^{\prime \prime}$ is $\varepsilon \sigma T_{s}^{4}$, where $\varepsilon$ is the longwave emissivity of the ice or snow surface, $\sigma$ is the Stefan-Boltzmann constant, and $T_{s}$ is AVHRR channel 4 temperature $[Y u$ et al., 1995]. There are several parameterizations for downward longwave radiation $F_{f}^{\mathrm{dn}}$. We used an empirical relation, $F_{l}^{\text {dn }}=\varepsilon^{*} \sigma T_{a}^{4}$, where $\varepsilon^{*}$ is an effective emissivity for the atmosphere, and $T_{a}$ is the surface air temperature $2 \mathrm{~m}$ above the surface [Maykut, 1985]. Because there were no simultaneous air temperature measurements at the times of the satellite observation, we used the mean AVHRR surface temperature plus a bias as the surface air temperature.

The turbulent sensible heat flux $F_{s}$ and latent heat flux $F_{e}$ can be estimated from

$$
\begin{gathered}
F_{s}=\rho_{a} c_{p} C_{s} u\left(T_{a}-T_{s}\right) \\
F_{e}=\rho_{a} L C_{e} C_{s} u\left(f e_{s a}-e_{s 0}\right) .
\end{gathered}
$$

We chose $C_{s}=C_{e}, 0.003$ for very thin ice and 0.00175 for thicker ice. The surface $2 \mathrm{~m}$ wind speed $u$ is estimated according to $u=0.34 U_{G}$ [Fissel and Tang, 1991]; the geostrophic wind $U_{G}$ was derived from 12 hourly sea level pressure fields measured by Arctic buoys.

Assuming a linear temperature profile in the snow and thin ice, we can estimate the conductive heat flux as

$$
F_{c}=\gamma\left(T_{f}-T_{s}\right)
$$

where $\gamma=\left(k_{1} k_{s}\right) /\left(k_{s} h+k_{\imath} h_{s}\right)$ is the thermal conductance of the ice-snow slab and $T_{f}$ is the freezing temperature of seawater. The conductivity of the ice is determined by

$$
k_{t}=k_{o}+\beta S /\left(T_{i}-273\right) \text {. }
$$

Studies show that $k_{t}$ depends weakly on the temperature of the ice slab $T$, when it is below $-4^{\circ} \mathrm{C}$ [Maykut, 1985]; our sampled AVHRR surface temperatures were generally in this range. We thus used the surface temperature $T_{s}$ in place of $T$, in (8) and introduced no significant error. The sea ice salinity $S$ is determined empirically as formulated by Cox and Weeks [1974]:

$$
\begin{gathered}
S=14.24+19.39 h, h \leq 0.4 \mathrm{~m} ; \\
S=7.88+1.59 h, h>0.4 \mathrm{~m} .
\end{gathered}
$$

By reducing the thermal conductivity of the ice slab a thin layer of snow can obscure the relationship between surface temperature and thin ice thickness. This can cause considerable difficulty in estimating ice thickness from AVHRR data. Here we apply an empirical relationship between snow depth and ice thickness proposed by Doronin [1971]:

$$
\begin{gathered}
h_{s}=0, h<0.5 \mathrm{~m} ; \\
h_{s}=0.05 h, 5 \mathrm{~cm} \leq h \leq 20 \mathrm{~cm} ; \\
h_{s}=0.1 h, h>20 \mathrm{~cm} .
\end{gathered}
$$

A comparison shows a good agreement between an analytical growth computed with (10) and the predictions by Anderson [1958] and Zubov [1945]. Anderson's formula applies to conditions of little snow, whereas Zubov's applies to a thicker snow cover [Maykut, 1985].

The details of the algorithm, such as the derivation of surface temperature $T_{s}$, surface air temperature $T_{a}$, and surface albedo $\alpha_{s}$, were described by YR96, who also discussed the estimated uncertainties. The largest error comes from the downward longwave radiation and the sensible heat flux in winter. Solar radiation and surface albedo contribute another large portion in spring. Given the errors in the parameterized longwave radiation [Key et al., 1997] and in all other model inputs, the uncertainty of the cumulative distribution was about $3 \%$ for ice $20 \mathrm{~cm}$ thick and about $10 \%$ for ice around 1 $m$ thick. We show that in many cases these errors are significantly smaller than the variation in thin ice observed in different months and regions.

\subsection{Size of Sample Area}

Unlike a surface map showing what thickness of ice resides at which satellite pixel, the quantity we are interested in here is the thickness distribution over a surface area. An effective description of this quantity is the cumulative distribution

$$
G(h)=\frac{1}{R} A(0, h)
$$

where $\mathrm{A}$ is an area covered by ice with thickness $h \geq 0$ within a sampled region $R$. Here we refer to $G(1 \mathrm{~m})$ as the total fraction of ice thinner than $1 \mathrm{~m}$. Two factors are considered when choosing the size of the sampling region $R$ within an image: the sampling accuracy and the convenience of the calculation. Each pixel gives an independent sample since the autocorrelation falls to low values at the length scale of an AVHRR pixel. $G(h)$ can be constructed from a particular satellite scene with sampling proportion $\hat{G}=x / n$, where $x$ is the number of pixels with the specified attribute out of $n$, the total number of pixels in the scene. The standard deviation of a sample distribution of $\hat{G}$ is $\sigma_{\hat{G}}=\sqrt{ } G(1-G) / n$. We wanted to sample a range of very thin ice that covers 0.01 of the area to an accuracy of \pm 0.001 . This required $n=9900$ pixels, or an AVHRR image at least $100 \mathrm{~km}$ square.

To meet the sampling requirement, we arbitrarily divided the images into grid cells of $2^{\circ}$ latitude by $10^{\circ}$ longitude. Each of these cells represents a sample region $R$, within each we obtained $G(1 \mathrm{~m})$ according to (11) by counting the total number of pixels corresponding to ice thinner than $1 \mathrm{~m}$. Although the size of each cell varies with latitude, this cell division simplifies the computation and results in a sampling accuracy better than \pm 0.001 . The number of pixels in each cell may vary because of clouds. Any cell covered more than $70 \%$ by clouds was eliminated from our analysis, which left two to seven scenes available for each cell in a month. To estimate the "monthly" mean of total thin ice, we first calculated for each cell a "daily" cumulative fraction $G_{\text {I }}$ from each satellite scene and then averaged them by 

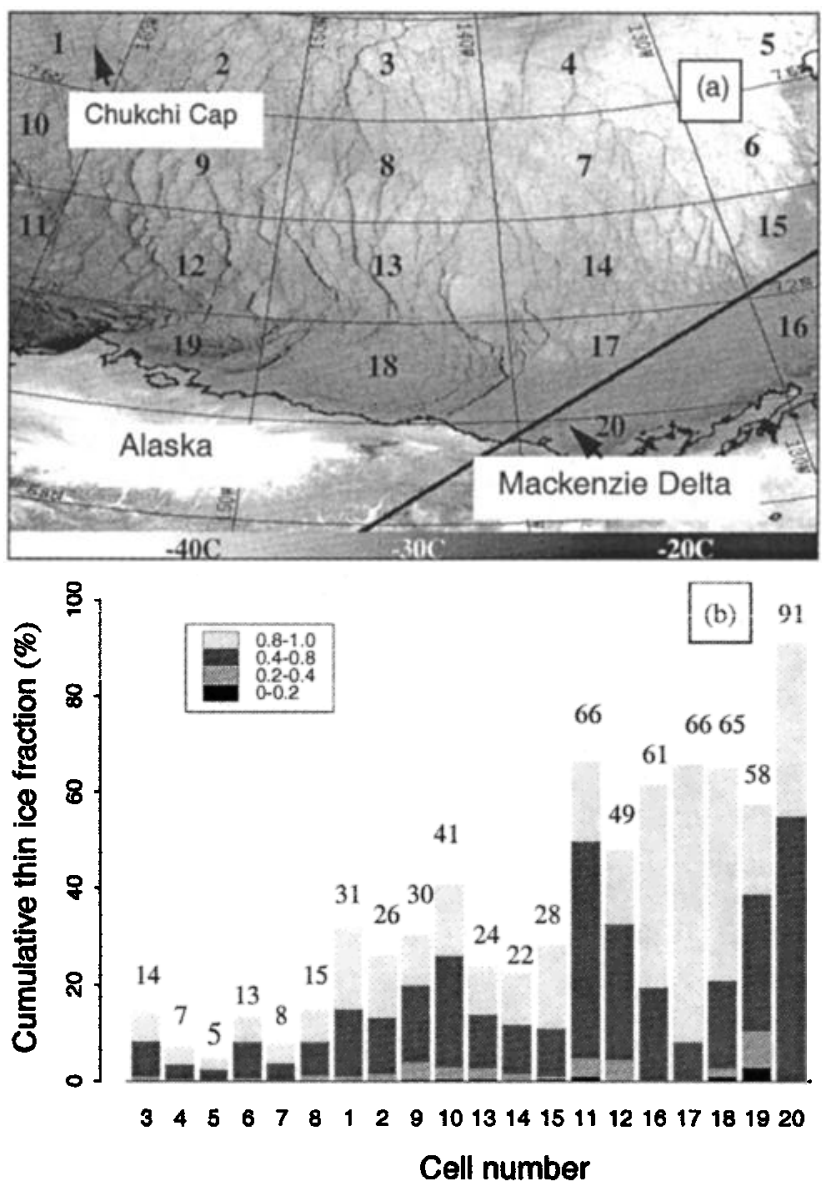

Figure 5. (a) AVHRR channel 4 surface temperatures in the Beaufort Sea on December 4, 1990. The cells from which thin ice distributions are derived are numbered from 1 to 20 . (b) The cumulative thin ice coverage for each cell, presented with vertical bars separated into four thickness categories. The values of $G(1 \mathrm{~m})$ are shown by the numbers at the top of each bar. (The black line in Figure $5 \mathrm{a}$ is due to data dropouts.)

$$
\bar{G}(1 \mathrm{~m})=\frac{1}{n} \sum_{i=1}^{n} G_{i}(1 \mathrm{~m})
$$

where $n$, ranging between two and seven, is the number of clear-sky scenes within a month. Our calculations show that values of $G_{i}(1 \mathrm{~m})$ fluctuated between 5 and $10 \%$ from scene to scene, comparable to the uncertainty of satellite observation. In section 3.3 we discuss $G_{i}(1 \mathrm{~m})$ and $\bar{G}(1 \mathrm{~m})$ in detail.

\subsection{Large-Scale Distribution}

3.3.1. The Beaufort Sea. A satellite scene of the Beaufort Sea typical of our December data is shown in Figure 5a. Increasing from the southern Canada Basin to the North American coast and the Chukchi Cap, the surface temperature ranged from $-47^{\circ}$ to $-18^{\circ} \mathrm{C}$, with a mean around $-36^{\circ} \mathrm{C}$. Against the background of cold ice floes, the lead network contrasts strongly with its dark (warm), narrow surface features.

Values of $G(1 \mathrm{~m})$ estimated for this particular day are illustrated in Figure 5b. The fraction was the lowest in the southern Canada Basin (cells 3-8) and higher from the western part of the Chukchi Sea to the North American coast. The largest fraction was observed over the Mackenzie River Delta (cell 20), where ice likely formed locally. Of all the thin ice observed, ice thicker than $40 \mathrm{~cm}$ made up the greatest proportion. New ice was rarely detected; most was in cell 19 where the coastal polynya frequently occurs.

Figure 6a displays the monthly mean of $\bar{G}(1 \mathrm{~m})$ for each cell in December 1990. Thin ice was nearly $60 \%$ of the ice on and near the shelf and $83 \%$ over the Mackenzie River Delta. For a comparison, thin ice covered only $10 \%$ in the southern Canada Basin.

In April 1991, which was in the late ice-growing season, the surface temperature rose by about $10^{\circ} \mathrm{C}$, causing less thermal contrast at the surface. The percentage of thin ice also declined; the averaged amount was $<2 \%$ (Figure $6 \mathrm{~b}$ ). This value was about 1 order of magnitude less than the observation in December.

3.3.2. The northern Greenland Sea. The ice cover here contained much multiyear ice as well as large fractions of
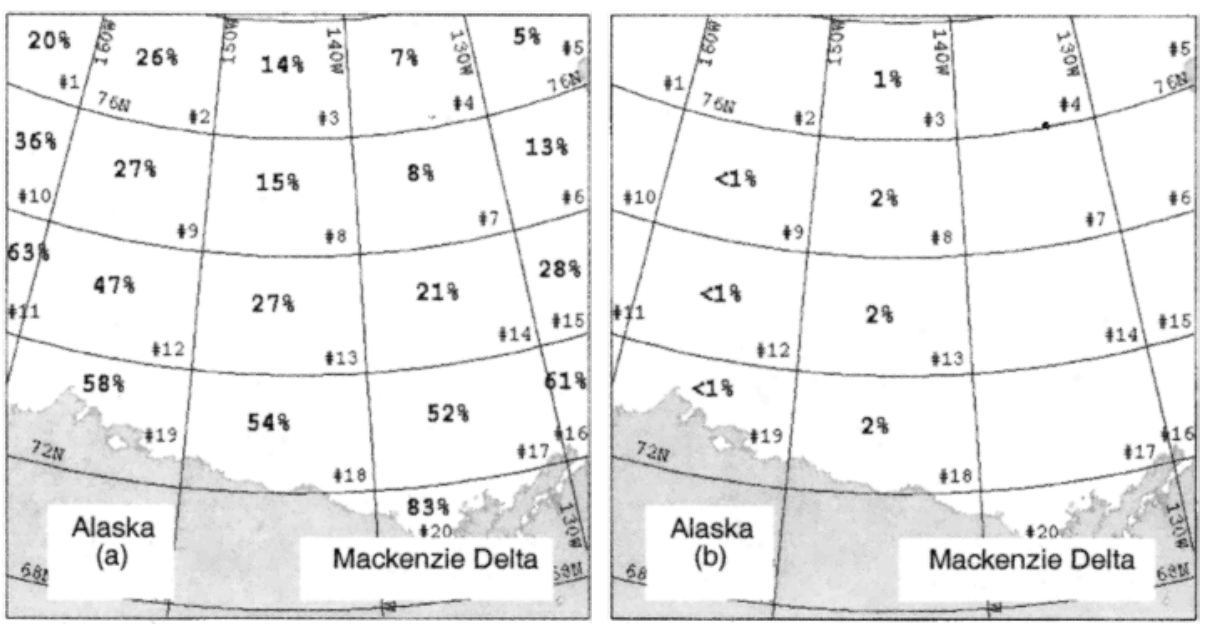

Figure 6. Percentage of ice up to $1 \mathrm{~m}$ thick in the Beaufort Sea in (a) December 1990 and (b) April 1991. The number in bold is the estimate for each grid cell. The small number at the lower right corner of each grid indicates the cell number. 

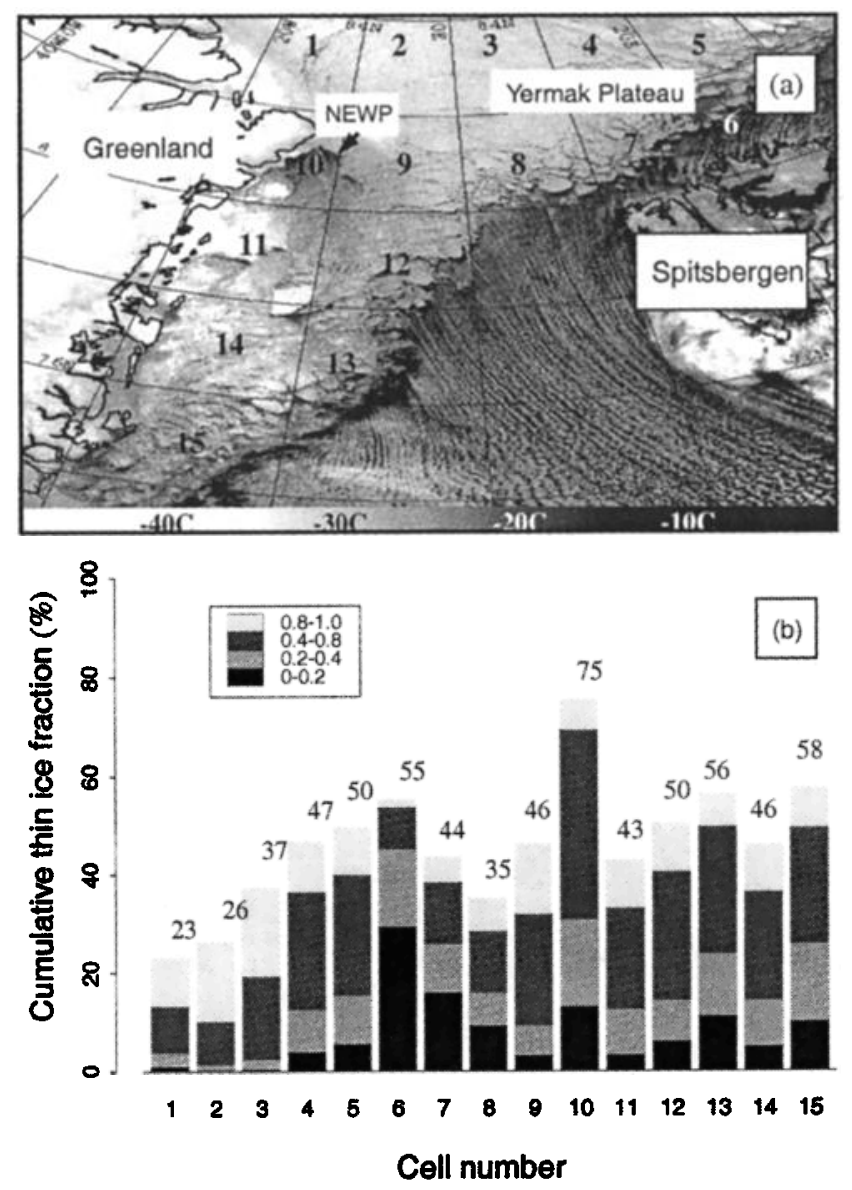

Figure 7. (a) AVHRR channel 4 surface temperatures in the Greenland Sea on November 12, 1990. The cells from which thin ice distributions are derived are numbered 1 to 15 . (b) The cumulative thin ice coverage for each cell, presented with vertical bars separated into four thickness categories. The values of $G(1 \mathrm{~m})$ are shown by the numbers at the top of each bar.

open water and thin ice. Figure $7 \mathrm{a}$ shows the observation by AVHRR on November 12, 1990. The temperatures ranged from $-48^{\circ}$ to $-10^{\circ} \mathrm{C}$, with a mean around $-33^{\circ} \mathrm{C}$. Note that the Northeast Water Polynya (NEWP) is visible in cell 10 on the East Greenland Shelf. Excluding the areas of open ocean beyond the ice edge, the remaining region contained $23-75 \%$ thin ice (Figure 7b). Its proportion was highest in cell 10 because of the NEWP and lowest in the northwest part of Fram Strait. Most new ice was observed in cells along the ice edge. Figure 8a shows $\bar{G}(1 \mathrm{~m})$ for November 1990; the spatial variation is similar to that shown in Figure $7 \mathrm{~b}$.

In contrast to the Beaufort region, the Greenland Sea contained a considerable amount of thin ice in April 1991 (Figure $8 b$ ). Except for the area north of $82^{\circ} \mathrm{N}, \bar{G}(1 \mathrm{~m})$ varied from 10 to $36 \%$ for the rest of the region. Thin ice retained its greatest proportion in cell 10 and was slightly less in the area north of Spitsbergen. A meridional variation was apparent along the East Greenland Current: $\bar{G}(1 \mathrm{~m})$ increased from $4 \%$ north of $82^{\circ} \mathrm{N}$ to $16 \%$ south of $76^{\circ} \mathrm{N}$.

To examine further the large-scale variation of AVHRRderived thickness distribution, we grouped cells of each region into three zones (Table 1). The grouping was based on large-scale ice conditions. The "perennial ice zone" (region 1) refers to areas over the deep basin that are covered mostly by multiyear ice, whereas the "seasonal ice zone" (region II) extends from the coasts to the shelves, where fast and firstyear ice are common. In between is a "transitional zone" (region III) containing, generally, the boundary of multiyear ice; shear deformation is more common in this area of the Beaufort Sea. On the basis of this grouping we estimated the mean of each zone for the Beaufort and the Greenland Seas. Table 2 compares the results: thin ice occupied $60 \%$ of the seasonal ice zone in the Beaufort Sea and $53 \%$ in the Greenland Sea. The latter, however, showed a higher coverage of thin ice over the rest of the region.

\section{Salt Flux from Growing Thin Ice}

\subsection{Estimating Flux As Averaged Property}

The difference in the amount of thin ice in the Beaufort and the northern Greenland Seas caused strong regional and seasonal differences in brine flux. Here we were interested in an average property over areas about $200 \mathrm{~km}$ square, which was weighted by the thin ice portion of the distribution. To be averaged regionally, salt flux $F_{\text {salt }}$ from growing thin ice was first estimated with a bulk formula at each satellite pixel:

$$
F_{\text {salt }}(h)=\rho_{i} f(h)\left[S_{w}-S_{i}(h)\right]
$$

where $f(h)=d H_{i} / d t=\left(\frac{1}{\rho_{i} L_{f}}\right)\left[F_{c}(h)-F_{w}\right]$ is the ice growth rate controlled by the difference between conduction of heat $\left(F_{c}\right)$ through the ice and oceanic heat flux $\left(F_{w}\right)$ to the bottom of the ice, $\rho_{i}$ is density of sea ice, $L_{f}$ is the latent heat of fusion, $S_{w}$ is the salinity of seawater, and $S_{i}$ is the initial salinity of sea ice. The ice salinity $S_{\text {, was determined from the relation } S_{t}}$ $=k_{\text {eff }} S_{w}$, where $k_{\text {eff }}$ is the effective distribution coefficient and is given by the empirical relationship [Cox and Weeks, 1988]:

$$
\begin{gathered}
k_{\text {eff }}=0.26 /\{0.26+0.74 \exp [-7243 f(h)]\}, f>3.6 \times 10^{-5} \mathrm{~cm} \mathrm{~s}^{-1} ; \\
k_{\text {eff }}=0.8925+0.0568 \ln f(h), \\
\quad 2.0 \times 10^{-6} \mathrm{~cm} \mathrm{~s}^{-1} \leq f \leq 3.6 \times 10^{-5} \mathrm{~cm} \mathrm{~s}^{-1} ; \\
k_{\text {eff }}=0.12, f<2.0 \times 10^{-6} \mathrm{~cm} \mathrm{~s}^{-1} .
\end{gathered}
$$

Note that in (14), $S$, is the ice salinity during the initial brine entrapment. As the newly grown ice ages, its initial salinity may be reduced by as much as $50 \%$ because of further desalination (H. Eicken, personal communication, 2000).

The salinity of surface water varies in both space and time. We used climatological values because of the lack of field measurements at the time of the satellite observations. For the Beaufort Sea we assumed a salinity of 31 psu for the seasonal zone in December and 30 psu for the rest [Melling and Lewis, 1982]. For the Greenland Sea we used a surface salinity of 34 psu for the transition zone and 32 psu for the rest [Aagaard and Coachman, 1968; Muench et al., 1992].

The oceanic heat flux $F_{w}$ required for $f(h)$ is one of the least observed parameters in the Arctic. A climatological mean of 2 $\mathrm{W} \mathrm{\textrm {m } ^ { - 2 }}$ [Maykut, 1985] was used for the whole Beaufort Sea. The distribution of ocean heat flux in the Greenland Sea is more complex because of strong spatial temperature gradients around the ice margin. We used the annual means simulated 

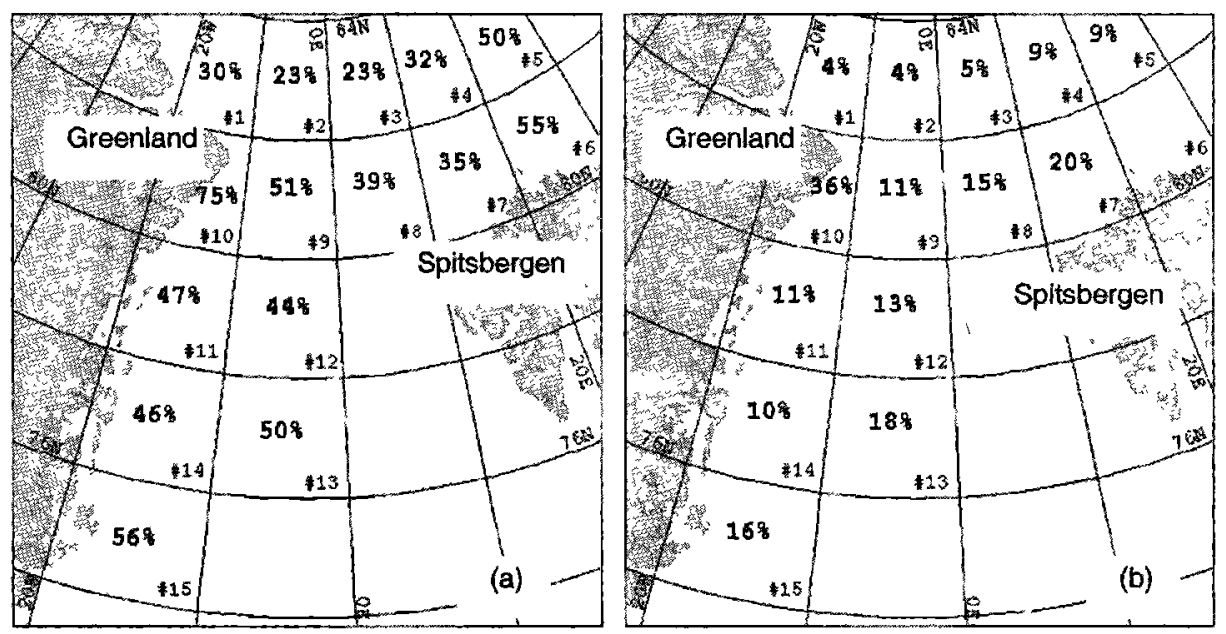

Figure 8. Percentage of ice up to $1 \mathrm{~m}$ thick in the Greenland Sea in (a) November 1990 and (b) April 1991. The number in bold is the estimate for each grid cell. The small number at the lower right corner of each grid indicates the cell number.

by the numerical model of Hibler and Bryan [1987]. According to the model the average annual heat gained by the upper layer of the ocean on the eastern Greenland shelf increases both eastward and southward. It is generally $<5 \mathrm{~W}$ $\mathrm{m}^{-2}$ north of $80^{\circ} \mathrm{N}, 5-24 \mathrm{~W} \mathrm{~m}^{-2}$ on the shelf, and as large as 53 $\mathrm{W} \mathrm{m}^{-2}$ adjacent to the shelf break. We assumed all the heat supplied to the upper ocean reaches the bottom of the ice, as reflected in $F_{w}$, which was estimated by interpolating the results in Figure 16 of Hibler and Bryan over each cell. Table 3 shows the values for the Greenland Sea. Given all known variables in (13), we estimated the salt flux first at each satellite pixel and then averaged within four ice thickness categories, $0-0.2,0.2-0.4,0.4-0.8$, and $0.8-1.0 \mathrm{~m}$ :

$$
\bar{F}_{\text {salt }}=\sum_{j=1}^{4}\left(\bar{F}_{\text {salt }}\right)_{j} \Delta G_{j}
$$

where $\left(F_{\text {salt }}\right) j$ is the mean flux in the $j$ th category and $\Delta G j$ is the cumulative ice thickness distribution defined as the fraction of an area with ice thickness between $h_{j}$ and $h_{j-l}$. It is the area-weighted flux from thin ice, $\bar{F}_{\text {salt }}$, that is discussed here in detail.

\subsection{Large-Scale Variations}

As the salt flux strongly depends on ice growth, we first show in Table 4 the area-weighted growth rates for ice $<1 \mathrm{~m}$ thick. The values were estimated as described by (15). Rapid growth was observed over the seasonal ice zones and in the transition zone in the Greenland Sea. Because of satellite resolution, the algorithm performed the best over areas where leads were wide or the density of thin ice was high, such as in the Mackenzie River Delta (cell 20 in the Beaufort Sea), where the area-weighted ice growth rate was about $0.96 \mathrm{~cm} \mathrm{~d}^{-1}$ in December 1990. If we take this value as the average growth around the delta in the winter of 1990/1991 and assume the surface water started to freeze in mid-October of 1990 (as observed in a field experiment [Macdonald et al., 1995]), we obtain ice $1.7 \mathrm{~m}$ thick by mid-April 1991. According to the same field observation, ice in this area retained its growth until at least early May 1991, and the mean ice thickness measured from 27 ice cores was $1.9 \mathrm{~m}$. In this case the satellite estimate agreed reasonably well with the field observation.

The area-weighted salt flux for the Beaufort Sea is shown in Figure 9. A large-scale variation was apparent in December 1990 (Figure 9a): the salt flux from thin ice reached more than $0.1 \mathrm{~kg} \mathrm{~m}^{-2} \mathrm{~d}^{-1}$ along the coast and decreased by an order of magnitude toward the deep basin. The largest contribution came from the Mackenzie River Delta. Together with the Beaufort Shelf and the western part of the Chukchi Sea, thin ice produced, on average, a salt flux of $0.16 \mathrm{~kg} \mathrm{~m}^{-2} \mathrm{~d}^{-1}$, which was twice as much as that of the transition zone. This observation showed an important contribution of the Beaufort Shelf to the Arctic Ocean halocline. A comparison of the November/December 1990 and April 1991 observations is shown in Figure 9b. Although the clouds limited our observation, the brine flux from thin ice was clearly less significant during this time of the year.

Both the shelf and the area north of Spitsbergen in the northern Greenland Sea received a large amount of the salt from growing thin ice in November 1990 (Figure 10a); the

Table 1. Zones Defined for the Beaufort and the Northern Greenland Seas

\begin{tabular}{lccc}
\hline \multicolumn{1}{c}{ Zone } & Perennial & Transitıonal & Seasonal \\
\hline $\begin{array}{l}\text { Cell number } \\
\text { (Beaufort Sea) }\end{array}$ & $3,4,5,6,7,8$ & $1,2,9,10,13,14,15$ & $11,12,16,17,18,19,20$ \\
$\begin{array}{l}\text { Cell number } \\
\text { (Greenland Sea) }\end{array}$ & $1,2,3$ & $4,5,6,7,8$ & $9,10,11,12,13,14,15$ \\
\hline
\end{tabular}


Table 2. Cumulative Distribution $G(1 \mathrm{~m})$ Averaged for Each Zone

\begin{tabular}{lccccc}
\hline \multirow{2}{*}{ Region } & Month & \multicolumn{3}{c}{ Zones, \% } & \multirow{2}{*}{ Regional Mean, \% } \\
\cline { 3 - 5 } & & & Perennial & Transitional & Seasonal \\
\hline \multirow{2}{*}{ Beaufort Sea } & Dec. 1990 & 10 & 27 & 60 & 32 \\
& April 1991 & 1 & $<1$ & $<1$ & $<1$ \\
Greenland Sea & Nov. 1990 & 25 & 42 & 53 & 40 \\
& April 1991 & 4 & 13 & 16 & 11 \\
\hline
\end{tabular}

largest value observed was in cell 10 . Near the ice margin and down to the south the total surface salt flux decreased because of the enhanced heat flux from the ocean, which slowed the growth and favored some melting. The salt flux was 1-2 orders of magnitude less in April 1991 (Figure 10b) than was observed in the previous November. The largest value remained in cell 10 because of the high growth rate retained in the NEWP.

Besides leads imbedded among ice floes and polynyas along the coasts, there is another convective feature, the socalled Odden ice tongue, which frequently occurs in the central Greenland Sea around $72^{\circ}-74^{\circ} \mathrm{N}$. While this area is near the southern edge of our study region and the ice feature did not show up in our satellite images, the ice production can be high in the region of Nordbukta (a bay between the Odden ice tongue and the east Greenland ice pack). This high growth increases the density of surface water within the area of Nordbukta, leading to a regional overturning and convection [Wadhams et al., 1996].

There are uncertainties in our estimates; a portion involves the satellite sensor and some is from the estimate itself. AVHRR has a spatial resolution of $1-2 \mathrm{~km}$ at which the satellite cannot separate subpixel leads from the cold ice floes but rather "sees" a mixture of the warm and cold surfaces. As shown by YR96, the averaging may cause an overestimate of ice thickness from satellite data in some areas and an underestimate in others, depending on the character of the sampled surface. When thin ice fractions derived from AVHRR were compared with observations from ULS moorings, no bias was detected, and the standard deviation of the

Table 3. Oceanic heat flux $F_{w}$, in $\mathrm{W} \mathrm{m}^{-2}$, for each cell in the Greenland Sea

\begin{tabular}{rr}
\hline Cell & $F_{w}$ \\
\hline 1 & 2 \\
2 & 2 \\
3 & 2 \\
4 & 2 \\
5 & 2 \\
6 & 14 \\
7 & 14 \\
8 & 14 \\
9 & 2 \\
10 & 2 \\
11 & 14 \\
12 & 38 \\
13 & 38 \\
14 & 14 \\
15 & 38 \\
\hline
\end{tabular}

averaged difference was $<0.02$ for each $10 \mathrm{~cm}$ bin. Because an ULS measures ice thickness at a high frequency, typically 5 min per sample, the sonar is capable of resolving most of the fine leads. The comparison results suggest that the signals of subpixel features act more like background noise in AVHRR observation. As our estimate uncertainty in $G(h)$ was about $3 \%$ for ice $20 \mathrm{~cm}$ thick and $10 \%$ for $1 \mathrm{~m}$, comparable to the difference between the AVHRR and ULS measurements, an uncertainty of $10 \%$ at $G(1 \mathrm{~m})$ seems to be adequate to address the noise due to subpixel averaging. In this study we thus took $10 \%$ as the total error and spread it out evenly in each 10 $\mathrm{cm}$ bin. With another uncertainty, say $10 \mathrm{~W} \mathrm{~m}^{-2}$, from ocean heat flux [Perovich et al., 1989; Maykut and McPhee, 1995], we found that the error in area-weighted daily salt flux estimated from (15) varied by $\pm 0.04 \mathrm{~kg} \mathrm{~m}^{-2} \mathrm{~d}^{-1}$ for the middle of the growing season. With this small error, geophysical signals observed by AVHRR were strongest over the Arctic shelves during the winter season, thus enabling the satellite to detect spatial changes between the shelf and the deep basin, as well as seasonal variations between winter and spring.

We have so far limited our estimates to thin ice. Salt flux from growing thick ice are also significant if they occupy a large surface area. We next evaluate the relative contribution of both thin and thick ice to the total surface salt budget. To do so, we used a large-scale coupled ice-ocean model to estimate the salt flux from ice thicker than $1 \mathrm{~m}$ because its thickness distribution was not provided by AVHRR. With a spatial resolution of $40 \times 40 \mathrm{~km}$ the model has 12 categories of ice thickness and is forced by fields of geostrophic wind, surface air temperature, humidity, and paramerization of longwave radiation [Zhang et al., 1998]. The simulation was performed for the same regions and for the same time period as the AVHRR observations. On the basis of the model the thicker ice contributed a salt flux of $<0.01 \mathrm{~kg} \mathrm{~m}^{-2} \mathrm{~d}^{-1}$ over the two shelves during November/December of 1990 . This value was no more than $6 \%$ of the total salt budget, which contrasts sharply to the deep basins where about $67 \%$ of the total salt flux comes from the growth of thick ice. The impact of thin ice was apparently reduced because of the large proportion of thick ice in the perennial-ice-covered areas. Salt flux from thick ice was relatively small in our transition zones for November/December, accounting for only $11 \%$ of the total in the Beaufort Sea and $2 \%$ in the Greenland Sea. Clearly, AVHRR was capable of detecting nearly $90 \%$ of the total salt flux by thin ice growth in the seasonal ice zone.

The salinization of shelf water profoundly affects the Arctic halocline. As the salt releases during freezing, the surface mixed layer becomes denser than the underlying water. This gravitational instability promotes overturning of the water column, producing a well-mixed deeper subsurface layer. 
Table 4. Area-Weighted Thin Ice Growth Rate in Winter 1990/1991 Estimated in the Study Regions ${ }^{\mathbf{a}}$

\begin{tabular}{|c|c|c|c|c|c|c|}
\hline & \multicolumn{2}{|c|}{ Perennial, $\mathrm{cm} \mathrm{d}^{-1}$} & \multicolumn{2}{|c|}{ Transitional, $\mathrm{cm} \mathrm{d}^{-1}$} & \multicolumn{2}{|c|}{ Seasonal, $\mathrm{cm} \mathrm{d}^{-1}$} \\
\hline & Nov./Dec. & April & Nov./Dec & April & Nov /Dec. & April \\
\hline Beaufort Sea & 0.16 & 0.04 & 0.40 & 0.01 & 0.75 & 0.001 \\
\hline Greenland Sea & 0.34 & 0.08 & 0.81 & 020 & 0.85 & 0.15 \\
\hline
\end{tabular}

${ }^{\mathrm{a}}$ Values for November are from the Greenland Sea, and those for December are from the Beaufort Sea.

Through Ekman transport or coastal submarine channels this cold, dense shelf water will sink to the depth of equal salinity and later feed into the interior ocean [Aagaard and Roach, 1990]. With a higher salinity of surface water and a large surface area of thin ice the shelves produce the most ice volume and the largest brine flux in winter. For the whole basin the annual formation of dense water that feeds from the shelves to the Arctic Ocean is about $1-2.5 \mathrm{~Sv}\left(1 \mathrm{~Sv}=10^{6} \mathrm{~m}^{3}\right.$ $\mathrm{s}^{-1}$ ) [Aagaard et al., 1981]. Locally, the amount of saline water generated by freezing can vary among shelves and change with time. With CTD profiling measurements, Melling [1993] estimated a flux of $0.13 \mathrm{~Sv}$ off the Mackenzie Delta during the winter of $1980 / 1981$. Using Nimbus 7 multichannel microwave radiometer data, Cavalierl and Martin [1994] showed an annual rate of 0.51 Sv generated by the coastal polynyas along the coasts of North America and East Siberia between 1978 and 1987. Because AVHRR imagery covers a large surface area of the Arctic Basin and the satellite has a finer spatial resolution than a microwave sensor, the method we describe here provides much detailed spatial information and thus helps us gain a better understanding of the basin-shelf interaction.

\section{Compressive Ice Strength}

\subsection{Deriving Ice Strength From Thickness Distribution}

As ice strength $p^{*}$ depends on the distribution of the thin ice that participates in ridging, estimates of $G(h)$ derived from
AVHRR are well adapted for exploring the regional and seasonal variability of ice strength. To compare our estimates with modeled $p^{*}$ values, we use a slightly different version of (1) adopted specifically for numerical simulation [Flato and Hibler, 1995]:

$$
p^{*}=C_{f} C_{p} \int_{0}^{\infty} \omega(h) h^{2} d h,
$$

where $C_{f}$ is the ratio of total energy loss to potential energy change and typically is about $10-17$; this constant accounts for the energy dissipation during ridging. The value of $C_{p}$ is defined as a function of the acceleration due to gravity $\hat{g}$ and the densities of ice and water, $\rho_{l}$ and $\rho_{w}$ : $C_{p}=0.5\left(\rho_{1} / \rho_{w}\right) \hat{g}\left(\rho_{w}-\rho_{i}\right)$. The ridging mode $\omega(h)$ is estimated as

$$
\omega(h)=\frac{-\alpha(h) g(h)+\int_{0}^{\infty} \beta\left(h^{\prime}, h\right) \alpha\left(h^{\prime}\right) g\left(h^{\prime}\right) d h^{\prime}}{\int_{0}^{\infty}\left[\alpha(h) g(h)-\int_{0}^{\infty} \beta\left(h^{\prime}, h\right) \alpha\left(h^{\prime}\right) g\left(h^{\prime}\right) d h^{\prime}\right] d h}
$$

The participation function $\alpha(h)$ determines the distribution of ice breaking to build ridges, and it is calculated as

$$
\alpha(h)=\max \left\{\left[1-\frac{1}{C_{l}} \int_{0}^{h} g\left(h^{\prime}\right) d h^{\prime}\right], 0\right\} .
$$

By definition, $\alpha(h)$ is zero when $G=C_{l}$ (Figure 2). The constant $\mathrm{C}_{l}$ defines the percentage of thin ice available for ridging; the value of $\mathrm{C}_{l}$ is not well known. Rothrock and Hall [1975] suggested it could be as low as $5 \%$ on the basis of their
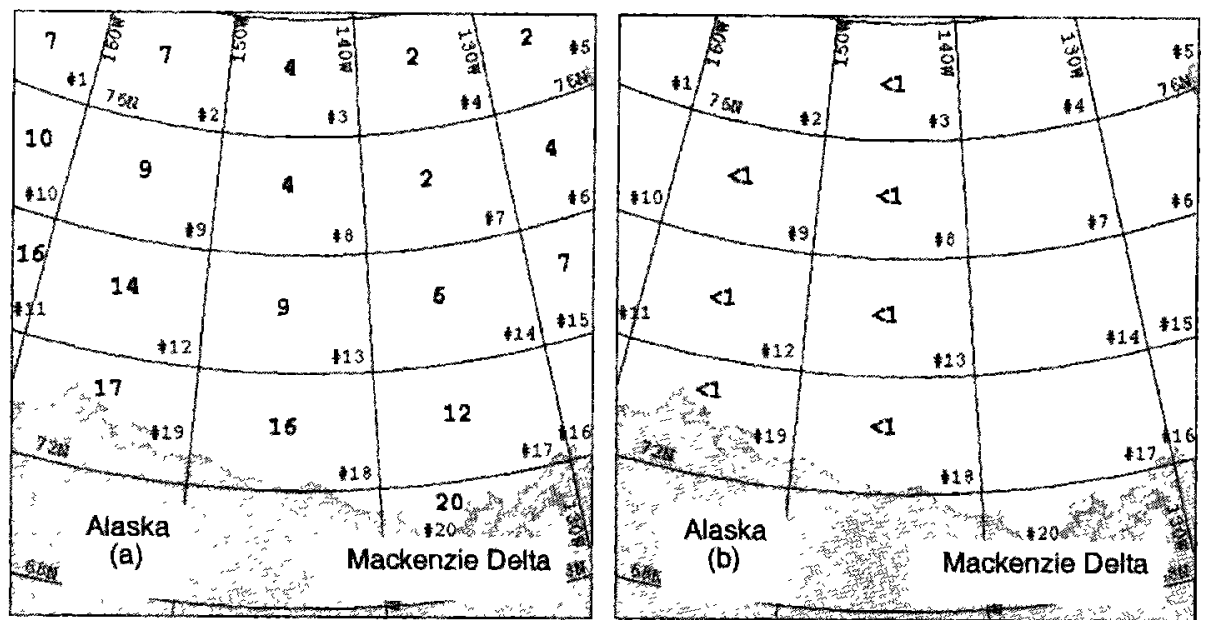

Figure 9. Area-weighted salt flux due to growth of thin ice in the Beaufort Sea in (a) December 1990 and (b) April 1991. The number in bold is the estimate for each grid cell in units of $10^{-2} \mathrm{~kg} \mathrm{~m}^{-2} \mathrm{~d}^{-1}$. The small number at the lower right corner of each grid indicates the cell number. Cells that have no data are left blank. 

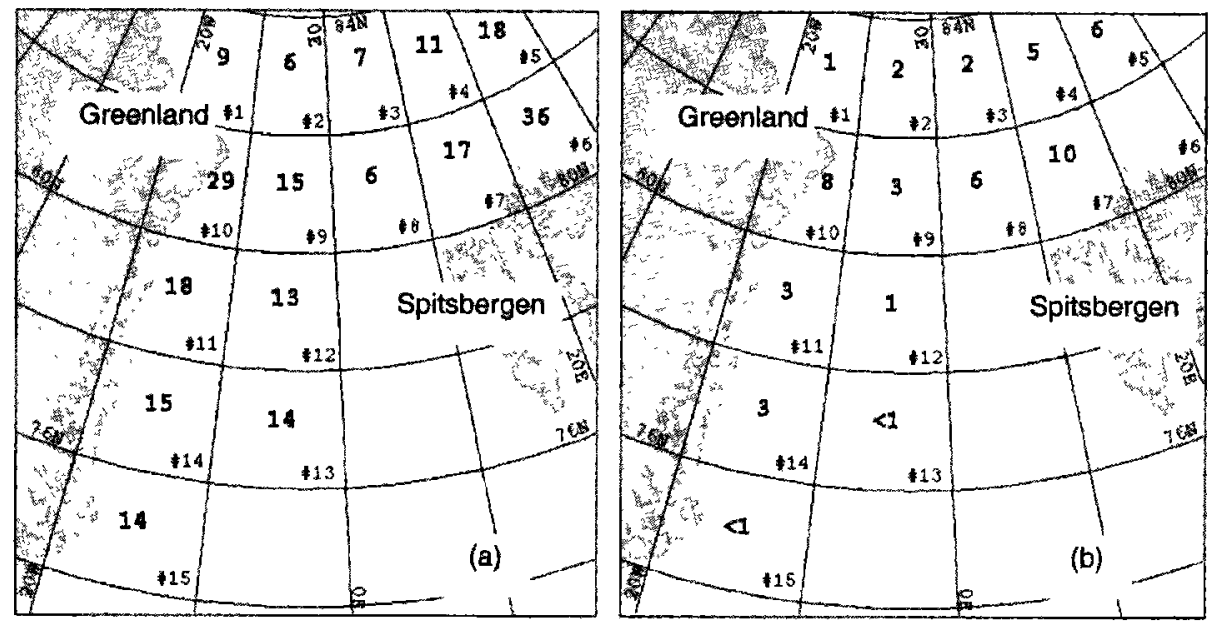

Figure 10. Area-weighted salt flux due to growth of thin ice in the Greenland Sea in (a) November 1990 and (b) April 1991. The number in bold is the estimate for each grid cell in units of $10^{-2} \mathrm{~kg} \mathrm{~m}^{-2} \mathrm{~d}^{-1}$. The small number at the lower right corner of each grid indicates the cell number. Cells that have no data are left blank.

observations, whereas Flato and Hibler [1995] justified a higher value of $15 \%$ in their model, a value suggested as plausible by Thorndike et al. [1975]. In this paper we chose an intermediate value of $10 \%\left(\mathrm{C}_{l}=0.1\right)$, as we are mainly interested in examining the relative values of $p^{*}$.

The function $\beta\left(h^{\prime}, h\right)$ in (17) describes the distribution of ridged ice made from an area of ice with some particular thickness. We calculated this function with the expression from Flato and Hibler [1995]:

$$
\beta\left(h^{\prime}, h\right)=\frac{1}{2\left(H^{*}-h^{\prime}\right)}, \quad 2 h^{\prime} \leq h \geq 2 \sqrt{H^{*} h^{\prime}},
$$

where the constant $H^{*}$ is $100 \mathrm{~m}$, which implies that the maximum ridge thickness is 20 times the square root of the thickness of the parent ice sheet. By solving (16)-(19) we derived the compressive ice strength $p^{*}$ for cells from each satellite image.

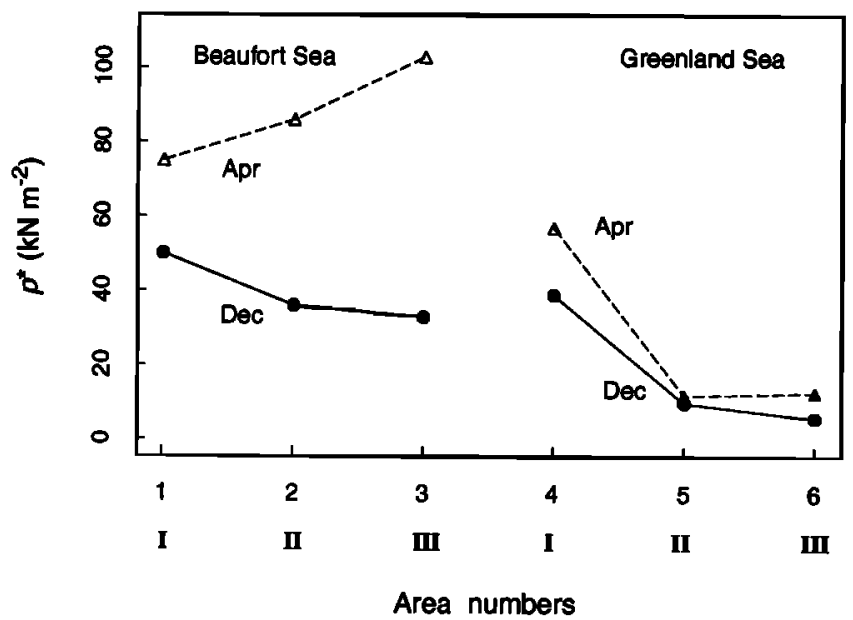

Figure 11. Spatial and temporal variations in compressive ice strength estimated from AVHRR for November and December 1990 and April 1991. Areas with $G(1 \mathrm{~m})<10 \%$ are plotted with open symbols. The Roman numbers correspond to the three zones defined previously: I, perennial; II, transitional; and III, seasonal.

\subsection{Spatial and Temporal Variations}

We assume that the thinnest $10 \%$ of the ice participates in ridging and thus affects $p^{*}$. This restriction requires that the cumulative distribution $G(1 \mathrm{~m})$ must be at least $10 \%$ for a surface area. For areas where $G(1 \mathrm{~m})$ is $<10 \%$, we estimate approximate $p^{*}$ values and take them as a lower bound on the real values.

Figure 11 shows the large-scale variation in ice strength for cells containing at least $10 \%$ thin ice. These values were averaged over each ice zone in the Beaufort and the northern Greenland Seas. In the winter months, $p^{*}$ is high over the deep basins (region I) and lower over transitional (region II) and seasonal ice zones (region III). Ice in the Greenland Sea, on average, had nearly half the strength of ice in the Beaufort Sea, i.e., 18 versus $40 \mathrm{kN} \mathrm{m}^{-2}$.

As the thin ice surface declines in the late part of the ice growing season, the ice pack as a whole gains strength. The

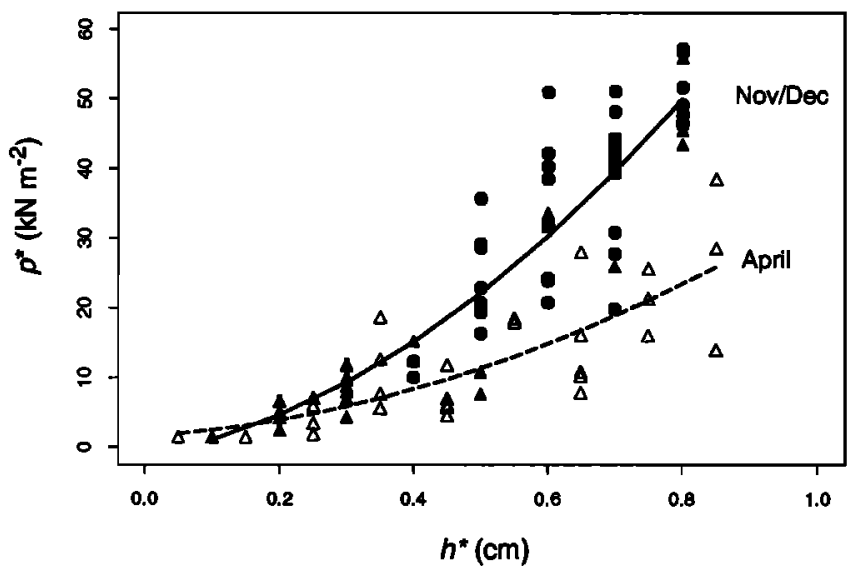

Figure 12. Relationship between $h^{*}$ and mean compressive ice strength $p^{*}$ for individual cells. The November/December values are plotted with solid symbols, and the April values are plotted with open triangles. The circles are for the Beaufort Sea, and the triangles are for the Greenland Sea. Lines represent the polynomial fit for the winter months (solid) and for April (dashed). 
value of $p^{*}$ in the Greenland Sea increased in April 1991 and was nearly doubled over the shelf. Comparative spring values are also shown for the Beaufort Sea and the northeast part of the Greenland Sea (open symbols in Figure 11). The high strength in this month resulted from a shortage of the thin ice that is needed to build pressure ridges. For instance, $p^{*}$ was the highest over the seasonal ice zone (III) in the Beaufort Sea in April 1991, when the thickest ice that joins the ridging was over $1 \mathrm{~m}$ thick.

We illustrate further (Figure 12) the relationship between $p^{*}$ and $h^{*}$, which is defined similarly to Thorndike et al. [1975] as the characteristic thickness at which $G\left(h^{*}\right)$ is just below or at $10 \%$ (i.e., $h^{*}$ indicates the thickest ice that participates in ridging). Note that the spring $p^{*}$ values were all from the Greenland Sea. During the winter the ice strength was generally higher in the Beaufort Sea (solid circles) than in the Greenland Sea (solid triangles). Ice strength increased exponentially with $h^{*}$, more rapidly when the characteristic thickness reached about $0.5 \mathrm{~m}$. This pattern was more prominent in winter than in spring.

The variation of $p^{*}$ also depends largely on the shape of the thin ice thickness distribution. Figure 13 shows the estimates of $G(h)$ averaged for each region and month, with $h^{*}$ marked for each distribution. The value $h^{*}$ varied with time and location: $h^{*}$ was about $0.6 \mathrm{~m}$ for the Beaufort Sea in December, $0.25 \mathrm{~m}$ for the Greenland Sea in November, and 0.45 $\mathrm{m}$ for the same region in April. We have no estimate of $h^{*}$ for the Beaufort Sea in April since the value exceeded the thickness limit of AVHRR. Nevertheless, the results in Figures 11-13 demonstrate the spatial and temporal variations in ice strength over a large scale. The study suggests that as the winter season progresses, the surface area covered by thin ice declines. This results in more thick firstyear ice involved in ridging, increasing the strength of the ice pack and its resistance to compression.

Ice strength is difficult to measure; our knowledge of its spatial and temporal variations comes mostly from models. In this study we took AVHRR-derived $p^{*}$ values as the "observed" and then compared them with predictions from the same large-scale numerical model (section 4.2). We used this model to simulate the ice thickness distribution and compressive ice strength over the Arctic from January 1990 to

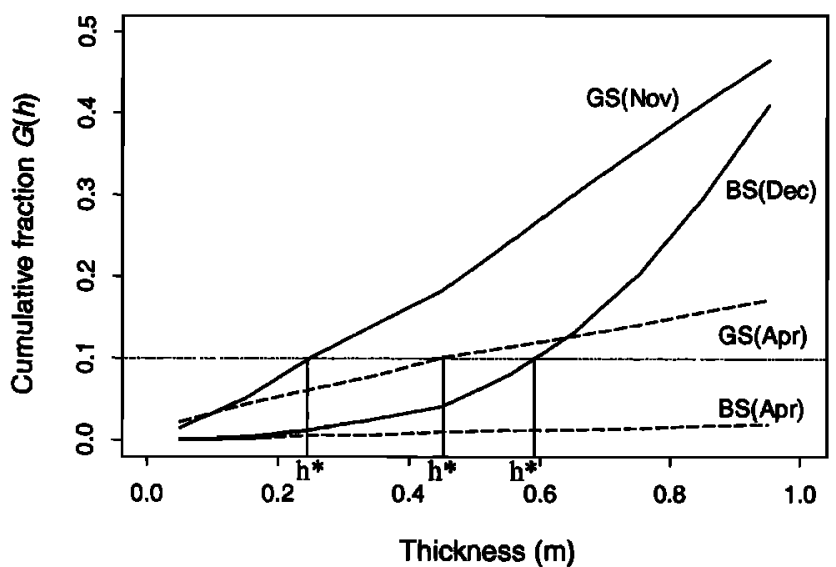

Figure 13. Mean cumulative distributions averaged over cells for each month and region. Label $h^{*}$ indicates the thickness at which $G(h)$ reaches $10 \%$. GS is the Greenland Sea, and BS is the Beaufort Sea.

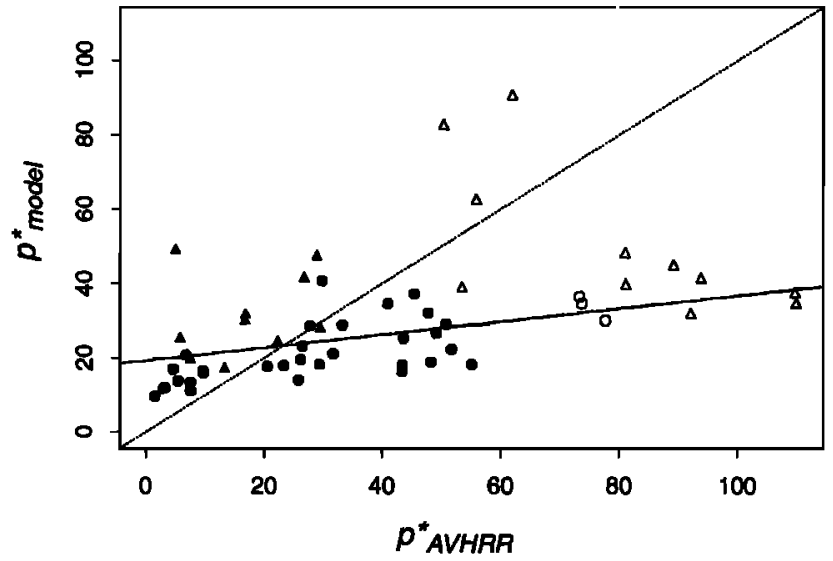

Figure 14. Comparison of AVHRR-derived $p^{*}$ with the simulations of the model. The values, in units of $\mathrm{kN} \mathrm{m}^{-2}$, are means averaged over each month for each cell. The solid circles are values for November/December 1990, and the solid triangles are for April 1991. The open symbols indicate cells in which AVHRR values are derived with $G(1 \mathrm{~m})<10 \%$. The solid line is a regression estimated from all points indicated by the solid symbols. The dotted line corresponds to a $1: 1$ ratio.

December 1991. The model contains a full thickness distribution and thus is not restricted by $1 \mathrm{~m}$ thick ice when simulating ice strength.

Figure 14 compares the $p^{*}$ values derived from AVHRR and from the model; both estimates were calculated with the same equations, (16)-(19), and the same constant, $C_{I}=10 \%$. To make comparisons for all AVHRR cells, we also plotted in Figure 14 the approximate $p^{*}$ values estimated for cells in which $G(1 \mathrm{~m})$ is less than $10 \%$. The approximate ice strengths from AVHRR are among the highest observed and much greater than the corresponding values simulated by the model. For AVHRR cells in which $G(1 \mathrm{~m})$ is $>10 \%$ the agreement is

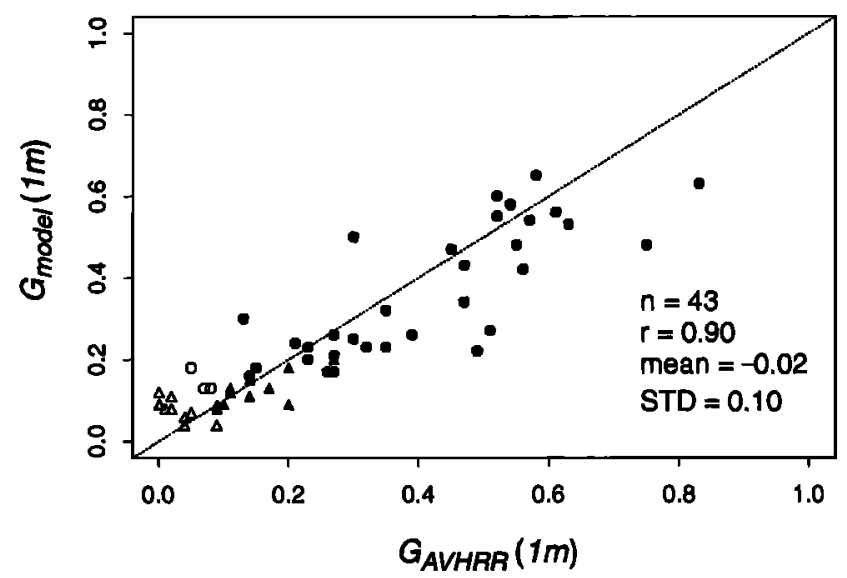

Figure 15. Relationship between thickness distributions of thin ice derived from AVHRR and simulated by the model, in percentage averaged over each month for each region. Winter values are represented by circles, and spring values are represented by triangles. The open symbols represent cells with $G(1 \mathrm{~m})<10 \%$, and the solid symbols represent cells with $G(1 \mathrm{~m})>10 \%$. The correlation coefficient, mean difference, and standard deviation of the difference are shown at the lower right corner. 
reasonable. However, except for the three highest triangles, there is much less variability in the modeled $p^{*}$ values. As the value derived from AVHRR increases, the difference between the two methods becomes larger.

To determine whether the less varied $p^{*}$ value predicted by the model results in a less varied $\mathrm{G}(h)$ according to (16) and (17), we show a scatterplot of the $G(1 \mathrm{~m})$ values derived from AVHRR versus those simulated by the model (Figure 15). The mean difference between the two estimates was about -0.02 , with a standard deviation 0.10 ; this value is within the range of uncertainty of satellite estimation. The correlation between the two types of estimates is 0.90 , suggesting that $G(h)$ is not the primary cause of the smaller variation in the modeled ice strength. Figure 12 shows a wide range in AVHRR-estimated $h^{*}$; its variability results in a large fluctuation in $p^{*}$, especially when $h^{*}$ is greater than about $0.5 \mathrm{~m}$. In contrast to the satellite observations for which we used the thickness increment of $0.10 \mathrm{~m}$, the model has only three bins at the thin end of the distribution, with boundaries at $0.10,0.43$, and 1.0 $\mathrm{m}$. This resulted in $58 \%$ of all model samples having an $h^{*}$ of $0.43 \mathrm{~m}$, with the remaining 20 and $22 \%$ at $h^{*}=0.1$ and $1.0 \mathrm{~m}$, respectively. The comparison of $p^{*}$ values derived from AVHRR and the model suggests that the larger spatial variation in the AVHRR-derived ice strength is most likely a result of the finer thickness categories at the thin end of the distribution. It is thus useful, when simulating large-scale ice strength and ice motion, to adopt a fine thickness grid at the thin end of the thickness distribution.

We have examined the spatial variations of $p^{*}$ for early (November/December 1990) and late (April 1991) ice-growing seasons. To put the satellite estimates into a perspective of seasonal variation, we show in Plate 2 a time series of ice strength simulated by the model for three selected cells from August 1990 to August 1991, along with the AVHRR-derived values for comparison. The modeled $p^{*}$ shows a distinct seasonal cycle in both seas. In general, ice strength is at its lowest in summer, climbs gradually after the fall freeze-up, becomes high during the winter, and then declines steeply during late spring and the summer melt. The ice strength derived from AVHRR was lower in three cases; however, it tracked reasonably well with the modeled seasonal cycle.

\section{Conclusions}

We combined temperatures and albedos derived from AVHRR with a thermodynamic ice model to estimate the thin ice thickness distribution for ice up to $1 \mathrm{~m}$ thick. The results are used to derive salt flux and compressive ice strength over the Beaufort and the northern Greenland Seas during 3 months: November and December 1990, representing the early part of the ice growing season, and April 1991, representing the later part of the growing season. In November and December, thin ice covered over half the area in the sampled seasonal ice zones and reached its greatest proportion at the Mackenzie River Delta in the Beaufort Sea and over the NEWP in the Greenland Sea. Compared with the Beaufort region, the Greenland Sea contained more thin ice in both winter and spring and showed smaller seasonal variations. The largest seasonal change in fraction of the thin ice was observed along the North American coast.

The thickness of thin ice derived from AVHRR is well adapted for exploring large-scale changes in both salt flux and compressive ice strength since both aggregate properties are strongly affected by the thickness distribution of thin ice. We demonstrate these applications and show that considerable information about salt flux and ice strength can be deduced from AVHRR imagery. As the satellite-derived estimates show, salt flux from growing thin ice on the Beaufort and Greenland Shelves was 1-2 orders of magnitude larger than in the deep basins and accounted for over $90 \%$ of the total surface salt flux budget.

The importance of shelf-produced dense flows in ventilating the Arctic Ocean is clear, but questions remain concerning their spatial scale and how seasonal and interannual variations affect shelf-basin interactions [Grebmeier et al., 1998]. This study demonstrates that the AVHRR-derived estimates can provide detailed spatial information on surface salt flux. This satellite information is of great use in studies of shelf-basin exchange and its affect on the Arctic thermohaline circulation.

Currently, the ridging process of Arctic pack ice is poorly understood. A recent study shows that sea ice can yield primarily in shearing, when compressive failure decreases through winter because of an increase in the ice strength [Overland et al., 1998]. Our satellite data indeed revealed a considerable seasonal change in the compressive ice strength. From November and December of 1990 to April 1991 the surface area of thin ice declined, leaving more thick first-year ice to be ridged and thus increasing the compressive strength of the ice pack. These changes will affect how the aggregate ice pack responds to deformation. Compared with results of a large-scale numerical model, AVHRR-derived ice strength showed more spatial variation, which was probably a result of the finer thickness categories derived from the satellite data. This suggests that a coarse resolution at the thin end of thickness distribution, as commonly adopted in the coupled ice-ocean models, could underestimate the variation in ice strength and thus the variability of ice motion.

Acknowledgments. We thank Hajo Eicken of the University of Alaska, Jeff Key of NOAA/ NESDIS, and reviewers for many helpful, constructive comments to improve the paper. This work is supported in part by EOS interdisciplinary investigations, Polar Exchange at the Sea Surface (POLES) under NASA grant NAGW-2407, and POLES2 under NASA grant NAG5-4375.

\section{References}

Aagaard, K., and L. K. Coachman, The East Greenland Current north of Denmark Strait; part I, Arctıc, 21, 181-200, 1968.

Aagaard, K., and A. T. Roach, Arctic Ocean-shelf exchange: Measurements in Barrow Canyon, J. Geophys. Res., 95, 18,163-18,175, 1990.

Aagaard, K., L. K. Coachman, and E. C. Carmack, On the halocline of the Arctic Ocean, Deep Sea Res., Part A, 28, 529-545, 1981.

Anderson, D. L., Growth rate of sea ice, J. Glaciol., 3, 1170-1172, 1958.

Cavalieri, D. J., and S. Martin, The contribution of Alaskan, Siberian, and Canadian coastal polynyas to the cold halocline layer of the Arctic Ocean, J. Geophys, Res., 99, 18,343-18,362, 1994.

Cox, G. F. N., and W. F. Weeks, Numerical simulations of the profile properties of undeformed first-year sea ice during the growth season, J. Geophys. Res., 93, 12,449-12,460, 1988.

Cox, G. F. N., and W. F. Weeks, Salinity variations in sea 1ce, $J$. Glaciol., I3, 109-120, 1974.

Doronin, Y. P., Thermal Interaction of the Atmosphere and the Hydrosphere in the Arctic, 85 pp., Coronet Books, Philadelphia, 1971.

Fissel., D. B., and C. L. Tang, Response of sea ice drift to wind forcing on the northeastern Newfoundland shelf, J. Geophys. Res., 96, $18,397-18,409,1991$

Flato, G. M., and W. D. Hibler III, Ridging and strength in modeling the thickness distribution of Arctic sea ice, J. Geophys, Res., 100, 18.611-18,626. 1995 
Grebmeier, J. M. et al (Eds.), Arctic system science ocean-atmosphereice interactions western Arctic Shelf-Basin interactions science plan ARCSS/OAII Rep. 7, 65 pp., Old Dominion Univ., Norfolk, VA, 1998.

Hibler, W. D., III, and K. Bryan, A diagnostic ice-ocean model, J. Phys. Oceanogr., 17, 987-1015, 1987.

Key, J. R., A. J Schweiger, and R. S. Stone, Expected uncertainty in satellite-derived estimates of the surface radiatıon budget at high latitudes, J. Geophys. Res., 102, 15,837-15,847, 1997.

Macdonald, R. W., D. W. Paton, and E. C. Carmack, The freshwater budget and under-ice spreading of Mackenzie River water in the Canadian Beaufort Sea based on salinity and ${ }^{18} \mathrm{O} /{ }^{16} \mathrm{O}$ measurements in water and ice, J. Geophys. Res., 100, 895-919, 1995.

Maykut, G. A., An introduction to ice in the polar oceans, Rep. APL-UW TR 8510, 107 pp., Appl. Phys. Lab., Univ. Wash., Seattle, 1985.

Maykut, G. A., and M. G. McPhee, Solar heating of the Arctic mixed layer, J. Geophys. Res., I00, 24,691-24,703, 1995.

Melling, $H$., The formation of a haline shelf front in wintertime in an ice-covered arctic sea, Cont. Shelf Res, 13, 1123-1147, 1993.

Melling, H., and E. L. Lewis, Shelf drainage flows in the Beaufort Sea and their effect on the Arctic Ocean pycnocline, Deep Sea Res, Part A, 29, 967-985, 1982.

Muench, R. D., M. G. McPhee, C. A. Paulson, and J. H. Morison, Winter oceanographic conditions in the Fram Strait-Yermak Plateau regıon, J. Geophys. Res., 97, 3469-3483, 1992.

Overland, J. E., S. L. McNutt, S. Salo, J. Groves, and S Li, Arctic sea ice as granular plastic, J. Geophys. Res., I03, 21,845-21,867, 1998.

Perovich, D. K., W. B. Tucker III, and R. A. Krishfield, Oceanic heat flux in the Fram Strait measured by a drifing buoy, Geophys. Res. Lett., 16, 995-998, 1989.

Rothrock, D. A., and R. T. Hall, Testing the redistribution of sea ice thickness from ERTS photographs, AIDJEX Bull., 29, 1-19, 1975.

Rothrock, D. A., The energetics of the plastic deformation of pack ice by ridging, J. Geophys. Res., 80, 4514-4519, 1975.
Shıne, K. P., and A. Henderson-Sellers, The sensitivity of a thermodynamic sea ice model to changes in surface albedo parameterization, J. Geophys. Res., 90, 2243-2250, 1985.

Thorndike, A. S., D. A. Rothrock, G. A. Maykut, and R. Colony, The thickness distribution of sea ice, J. Geophys Res., 80, 4501-4513, 1975.

Wadhams, P., J. C. Comiso, E. Prussen, S. Wells, M. Brandon, E. Aldworth, T. Viehoff, R. Allegrino, and D. R Crane, The development of the Odden ice tongue in the Greenland Sea durıng winter 1993 from remote sensing and field observations, J. Geophys Res., 101, 18,213-18,236, 1996.

Yu, Y. and D. A. Rothrock, Thin ice thickness from satellite thermal imagery, J. Geophys. Res., 101, 25,753-25,766, 1996

Yu, Y., D. A. Rothrock, and R. W. Lindsay, The accuracy of sea ice surface temperature from AVHRR, J. Geophys. Res., 100, $4525-4532,1995$

Zhang, J., R. A. Rothrock, and M. Steele, Warming of the Arctic Ocean by a strengthened Atlantic inflow: Model results, Geophys Res. Lett., $25,1745-1748,1998$.

Zubov, N. N., L'dy Arktikı (Arctic Ice), Izdatel'stvo Glavsevmorputi, Moscow, 491 pp., 1945. (Translated from Russian by U.S. Naval Oceanographıc Office and American Meteorological Society, 1965.)

D.A. Rothrock, Y. Yu, and J. Zhang, Polar Science Center, Applied Physics Laboratory, University of Washington, 1013 N E. 40th Street, Seattle, WA 98105. (e-mail: yanling@apl.washington.edu; rothrock@apl.washington.edu; zhang@apl.washington.edu)

(Received March 21, 2000; revised March 26, 2001; accepted April 2, 2001.) 